\title{
SCIENTIFIC JOURNAL OF THE TERNOPIL NATIONAL TECHNICAL UNIVERSITY
}

\author{
Scientific Journal \\ Issued 4 times a year \\ Founded in September, 1996
}

№ 3 (91) 2018

Founder and publisher:

Ternopil Ivan Puluj National Technical University

List of journals ISSN 2522-4433

Copyright 10.06.2010 КВ № 16861-5624ПР

Recommended by the Scientific Council of the Ternopil Ivan Puluj National Technical University, Protocol No 8, 12.11.2018.

\section{Editorial board:}

P.V. Yasniy (Editor-in-Chief), R.M. Rogatynskyi (Associate Editor), B.G. Shelestovs'kyi (Executive Editor), O.Ye. Andreikiv, V.A. Andriychuk, Z.Ya. Blikharskyi, M.I. Bobyr, B.M. Gevko, L.D. Didukh, Ya.P. Dragan, M.P. Karpinskyi, V.A. Kryven, R.M. Kushnir, V.S. Loveikin, S.A. Lupenko, I.V. Lutsiv, J.J. Luchko, P.O. Marushchak, M.S. Mykhailyshyn, Z.T. Nazarchuk, G.M. Nykyforchyn, M.R. Petryk, M.I. Pidgurskyi, Ch.V. Pulka, M.V. Pryimak, P.D. Stukhlyak, G.T. Sulym, V.T. Troshchenko.

\section{International editorial board:}

J. Fraissard (France), J. Kaleta (Poland), Yu. M. Lapusta (France), T. Lagoda, (Poland) T. Lehtla (Estonia), G. Pluvinage (France), K. Smedley (USA), A. Swic (Poland), L. Toth (Hungary).

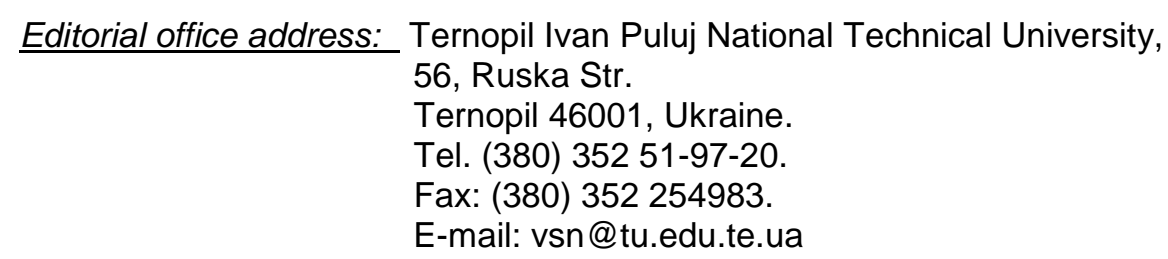

WWW-address: visnyk.tntu.edu.ua

Managing Editor L.Y. Petryshyna; Ye.I. Grytsenko

Art Editor, design, typist A.P. Katrych 


\title{
ВІСНИК ТЕРНОПІЛЬСЬКОГО \\ НАЦІОНАЛЬНОГО ТЕХНІЧНОГО УНІВЕРСИТЕТУ
}

\author{
Науковий журнал \\ Виходить 4 рази у рік \\ Заснований у вересні $1996 \mathrm{p}$. \\ № 3 (91) 2018 p.
}

Засновник і видавець:

Тернопільський національний технічний університет імені Івана Пулюя Реєстраційний номер ISSN 2522-4433.

Свідоцтво про державну реєстрацію друкованого засобу масової інформації серії КВ № 16861-5624ПР від 10.06.2010 p.

Рекомендовано до друку вченою радою Тернопільського національного технічного університету імені Івана Пулюя 12.11.2018 р., протокол № 8 .

\section{Редакційна колегія}

П.В. Ясній (головний редактор), Р.М. Рогатинський (заст. головного редактора), Б.Г. Шелестовський (відповідальний секретар), О.С. Андрейків, В.А. Андрійчук, 3.Я. Бліхарський, М.І. Бобир, Б.М. Гевко, Л.Д. Дідух， Я.П. Драган, М.П. Карпінський, В.А. Кривень, Р.М. Кушнір, В.С. Ловейкін, С.А. Лупенко, І.В. Луців, Й.Й. Лучко, П.О. Марущак, М.С. Михайлишин, 3.Т. Назарчук, Г.М. Никифорчин, М.Р. Петрик, М.І. Підгурський, М.В. Приймак, Ч.В. Пулька, П.Д. Стухляк, Г.Т. Сулим, В.Т. Трощенко.

\section{Міжнародна редакційна колегія}

Є. Калєта (Польща), Т. Лехтла (Естонія), Ю. М. Лапуста (Франція), Т. Лагода (Польща) Г. Плювінаж (Франція), А. Свік (Польща), К. Смедлі (США), Л. Тот (Угорщина), Ж. Фресад (Франція).

Адреса редакції: $\quad$ 46001, Тернопіль, вул. Руська, 56.

Тернопільський національний технічний університет імені Івана Пулюя.

Телефон: (0352) 51-97-20,

фракс: (0352) 254983.

E-mail:vsn@tu.edu.te.ua

WWW-address: visnyk.tntu.edu.ua

Редактори: Л.Й. Петришина; С.І. Гриценко

Комп'ютерне макетування А.П. Катрич

ISSN 2522-4433 


\section{CONTENT}

\section{MECHANICS AND MATERIALS SCIENCE}

Petro Yasniy; Oleksandr Dyvdyk; Nadiia Lutsyk; Volodymyr Yasnii. Modelling of mechanical behaviour of shape memory alloys using finite elements method.

Vasyl Trush; Alexander Luk'yanenko. Thermodynamic preconditions of the titanium compounds formation with interstitial elements $(\mathrm{C}, \mathrm{N}, \mathrm{O}, \mathrm{B})$ depending on temperature and pressure of gaseous medium.

Josef Luchko; Vitalii Kovalchuk; Ivan Kravets. Investigation of influence of the metal corrugated pipe diameter on its stress-strain state.

Danylo Stuklyak; Anna Sapronova; Vitaliy Yatsiyk; Bogdan Gryschuk. Influence of 2,4-diaminotoluene modifier on the physical and mechanical properties of epoxy composite coatings

Anatolii Vlasov; Nataliia Makarenko; Denys Holub; Hanna Kushchii; Vitalii Titarenko. Increasing of efficiency of manual arc welding and surfacing of engineering products.

Victor Revenko. Calculation of the plate plane stress in polar coordinate system on the basis of Lamé equation general solution.

Halyna Kramar; Lyudmyla Bodrova; Yaroslav Kovalchuk; Sergiy Marynenko; Ihor Koval. Effect of binder with nano $\mathrm{Ni}$ on mechanicalproperties of $\mathrm{TiC}$ based hard alloys....

Zakhar Yaskovets; Igor Orynyak. Numerical procedure based on basis and correction solutions for axial stress calculation in pipelines passing through zones of mine subsidence.

\section{MANUFACTURING ENGINEERING AND AUTOMATED PROCESSES}

Ihor Lutsiv; Vitalij Voloshyn; Valeriy Buhovets. Shape forming system model of lathes two-carriage tool systems.

Oleksandr Burya; Valentina Dubkova; Igor Pachkovski; Timothy Rybak; Iryna Rula. Hydrogen wear resistance under the metal-polymer friction pairs operation.

Roman Rogatynskyi; Taras Peleshok; Olena Rogatynska; Pavlo Les'kiv. Directed loading of the high-speed screw conveyor from the bunker.

Ann Tson; Nadia Khomuk; Taras Dovbush; Oleg Tson. Feasibility study of an auger conveyor performance of the haulm removing module. 


\section{INSTRUMENT-MAKING \\ AND INFORMATION-MEASURING SYSTEMS}

Mykhailo Palamar; Myroslava Yavorska; Mykhailo Strembitskyi; Volodymyr Strembitskyi. Selection of the efficient video data processing strategy based on the analysis of statistical digital images characteristics

\section{MATHEMATICAL MODELING. MATHEMATICS}

Anatolii Matsui; Vasyl Kondratets. Mathematical model of operative estimation of viscosity of a pulp in a ball mill at grinding an ore

Vyacheslav Nykytyuk; Vasyl Dozorskyi; Oksana Dozorska. Detection of biomedical signals disruption using a sliding window...

Volodymyr Gotovych; Oleg Nazarevych; Leonid Shcherbak. Mathematical modeling of the regular-mode electric power supply and electric power consumption processes of the organization.

Yuri Palaniza; Evheniya Yavorska; Halyna Shadrina; Leonid Dediv. Phonocardiosignal as a periodically correlated stochastic process preprocessing algorithm structure grounding ...................................................... 


\title{
UDC 57.087:519.21
}

\section{PHONOCARDIOSIGNAL AS A PERIODICALLY CORRELATED STOCHASTIC PROCESS PREPROCESSING ALGORITHM STRUCTURE GROUNDING}

\author{
Yuri Palaniza; Evheniya Yavorska; Halyna Shadrina; Leonid Dediv
}

\author{
Ternopil Ivan Puluj National Technical University, Ternopil, Ukraine
}

\begin{abstract}
Summary. For the cardiovascular desease early diagnosis by the remote monitoring systems the fonokardiosyhnal (as periodically correlated random process) simultaneously registered with electrocardiosignal usage is proposed. An registered signal preproccesing procedure, groundet in this article, is carried out by the following algorithm: detrending procedure (the constant component of the signal (trend) reducing), smoothing (high noise suppression with minimal spectrum distortion and P-peacs offset locations), the P-peacs repeating intervals determination.

Key words: biosignal, cardiosignal, phonocardiogram, mathematical model, simulation model, verification, heart pathology detecting algorithms, MATLAB.
\end{abstract}

Statement of the problem. The cardiovascular system (CVS) state is the key integral indicator used to evaluate human health, To CVS pathological processes at an early stage of it progression identify in time diagnostic CVS state monitoring systems which would be able to easily integrate into the Ukrainian social and infrastructural realities development is very relevant [1]. The basis for such systems creating is appropriate programm and mathematical software that would allow to find informative and invariant biosignal signs whitch could be used for heart state diagnostic and are understandable and acceptable for physicians [2].

Analysis of the available investigations. The up-to-date diagnostic systems widely use the polycardiogram method [3] based on synchronously registered electrocardiogram (ECG), a phonocardiograph (FCG) and a sphygmogram (SG). The complete information about cardiovascular system state can be obtained only if several diagnosing methods are used simultaneously. In a number of scientific authors's works (M.A Kurshakov, P.E. Lukomsky, S.A. Lupenko, A.A. Selidovkina) is emphasized the advantages on such comprehensive approach. The work of most modern cardio-diagnostic systems («CARDIO +», «REOCOM Professional») is based on the various physical nature signals processing separately. The phonocardiosignal most completely represents a CVS activity as hemodynamic one and is an information carrier about its state in the terms of system and signal concept. In general, approaches to PCS processing could be divided into deterministic (spectral decompositions, in different basis decompositions) and stochastic. In particular, in the G.M. Osukhivska works for the tone signal processing (in compare to the PCS the heart tones range frequency is localized below the noise frequency range, and the tone energy is much higher than the murmurs energy), the concept of «relaxational multipulser» is introduced and the filter statistical method is applied using the stochastic signals energy theory (ETSS). Another approach to the cardiosignal representation in a form of finite-dimensional vector's coordinates superposition of cyclic rhythmically related random processes for as synchronously registered cardiosignals (SRCS) mathematical models is given in S.A Lupenko works $[4,5]$. Since SRCS statistical processing is carried out based on the signal rhythmic structure (rhythm function), as input data in such processing are the signal values, the discrete rhythm function, the number of signal's cycles and the number of zones it consists in each 
cycle $[4,5]$. This requires data sequences resampling and interpolation causing a significant amount of hardware and software resources usation, which is not suitable for smart wears (smart clothes) patient bio-indicators remote monitoring systems in a compact form factor.

The quality of the PCS processing is determined by its mathematical representation method [6] - the PCS mathematical model as a periodically correlated stochasic process (PCSP) of $\pi^{T}$, class was previously grounded [7, 8]. Such model has the means to combine the randomness with repetition properties in its structure, interpreting as a probability characteristics periodicity and determinisity the methods (synphase, component, filtering [9]) fore researched object processing and the polycardiogram CVS state diagnosing telemetry systems design.

The Objective of the work is the PCS synchronously registered with ECS as periodically correlation stochastic process preprocessing for the noise impact minimization.

Statement of the task. The PCS synchronously registered with ECS preprocessing taking into account its genesis mechanism for the noise impact minimization.

Experimental model. The algorithms for synphase method realization [10] can be integrated into modern computer diagnostic instruments, and its advantage over other methods is the number of hardware and computing resources reducing. The PCSP as a FCS model using allowed to consider the NERVOUS REGULATION influence (sinus node as a «rhythm driver»), detect changes in the heart ACTIVITY on the early disease stages by introducing a new informative invariant characteristics class - the spectral components obtained as a result of synphase method signal processing.

However, the synphase method requires the statistical material homogeneity which complicates the researches and the input sequence autocorrelation function period value detection, which in the PCS case, can be represented as heart duration mean value.

The autocorrelation function period value detection classic approach the autocorrelation function repetition period detection [2]. This method is sensitive to the input sequence length and the heart cycle phase structure, which makes it impossible to ensure the results repeatability. The heart rate variability (HRV) is traditionally estimated about by the ECG RR-intervals duration, although it is advisable to consider the PP-intervals duration, since the exatly $\mathrm{P}$-wave [11] is the beginning of a new heart cycle excitation originates in the sinoatrial (SA) node. The prevalence of RR-intervals estimating is due to the fact that the Rwave, especially in the second standard lead, is easiest to allocate from the electrocardiosignal during signal processing because it amplitude is the biggest one. For HRV registration there can be used not only ECG but some other methods for heart rate recording (rheography, plethysmography, the major arteries Doppler ultrasound, echocardiography, phonocardiography). Therefore, it is proposed to use an PP-interval value for every single heart cycle duration value detection, since the P-wave corresponds to the moment of the action potential (Schmidt-Voigt) activation. In order to further PCS usage in the remote monitoring systems [12] of the CVS state diagnostics at early disease stages, it is suggested to choose the PCSP as FCS model [7, 8] (since this model is adequate to the signal genesis nature) and the synphase processing method.

PCS as the CVS functional state data carrier also contains undesirable artefacts in particular: noises which emerge during the PCS registration (microphone displacement on the skin surface, the phonocardiograph contact bounce, external noises in an examination room); patient's body endogenous (respiration, intestinal peristalsis); phonocardiograph zero drift (trend). PCS preprocessing [13] is proposed to be carried out according to the following algorithm: signal detrending (trend and signal constant component elimination), smoothing (high-frequency noise reducing with minimal spectrum distortion and minimal P-wave location displacement), the P-wave repeatability period finding. 
The trend minimization classic approach [14] is a two-stage process applying. On the first stage, the sequence approximation is performed, for example, using $n$-th order Newton's polynomial. And on the second one, an calculated sequence from the signal and trend mixture additive subtraction (detrending) using the same $k$-th polynomial length, where $k<n$. However, in the FCS case where there are at least a breathing trend and parasitic $50 \mathrm{~Hz}$ component (network frequency) are present, the method is unsuitable because it does not allow eliminate both of these components simultaneously. In practice, a sequence of a highfrequency (HF) and notch filters are used in analogue electronics devices to, respectively, trend, constant signal component and $50 \mathrm{~Hz}$ power supply network impact on the cardiograph leads reducing. In our case, the synphase method is insensitive to the coherent components present in the signal, so there is no need to impacts elimination.

Since the developed algorithm is focused on its application in the patient's CVS state remote monitoring systems, so in order to trend minimization, it is proposed to use the hardware implementation the high-pass Bessel filter (Sallen-Key topology) implementation, which has uniform (flat) amplitude-frequency response characteristics (AFR) (minimal equiripple in passband), linear phase-frequency characteristic (PFR), and the constant group delay.

Throughout the bandwidth, the analogue Bessel filters are characterized by a almost constant group delay. This allows to save the signal shape passing through such a linear system, on condition that their spectrum is located in the filter bandwidth. Bessel's Discrete Filters do not have this property. The designed Bessel filter order is chosen according to an empirically formulated criterion [13]:

$$
K=\left(n \cdot\left(\frac{K_{f_{1}} \cdot f_{s}}{\Delta}\right)\right)<0,3,
$$

of where $n$ - the filter order; $K_{f_{1}}$ - the coefficient of attenuation at a $1 \mathrm{~Hz}$ frequency, times; $f_{s}$ - the coefficient attenuation at cutoff frequency; $\Delta=f_{s}-1$.

A 3-rd order filter with a cutoff frequency of $10 \mathrm{~Hz}$ with AFR and the PFR shown on the Figure 1 was synthesized as the result of choosing.

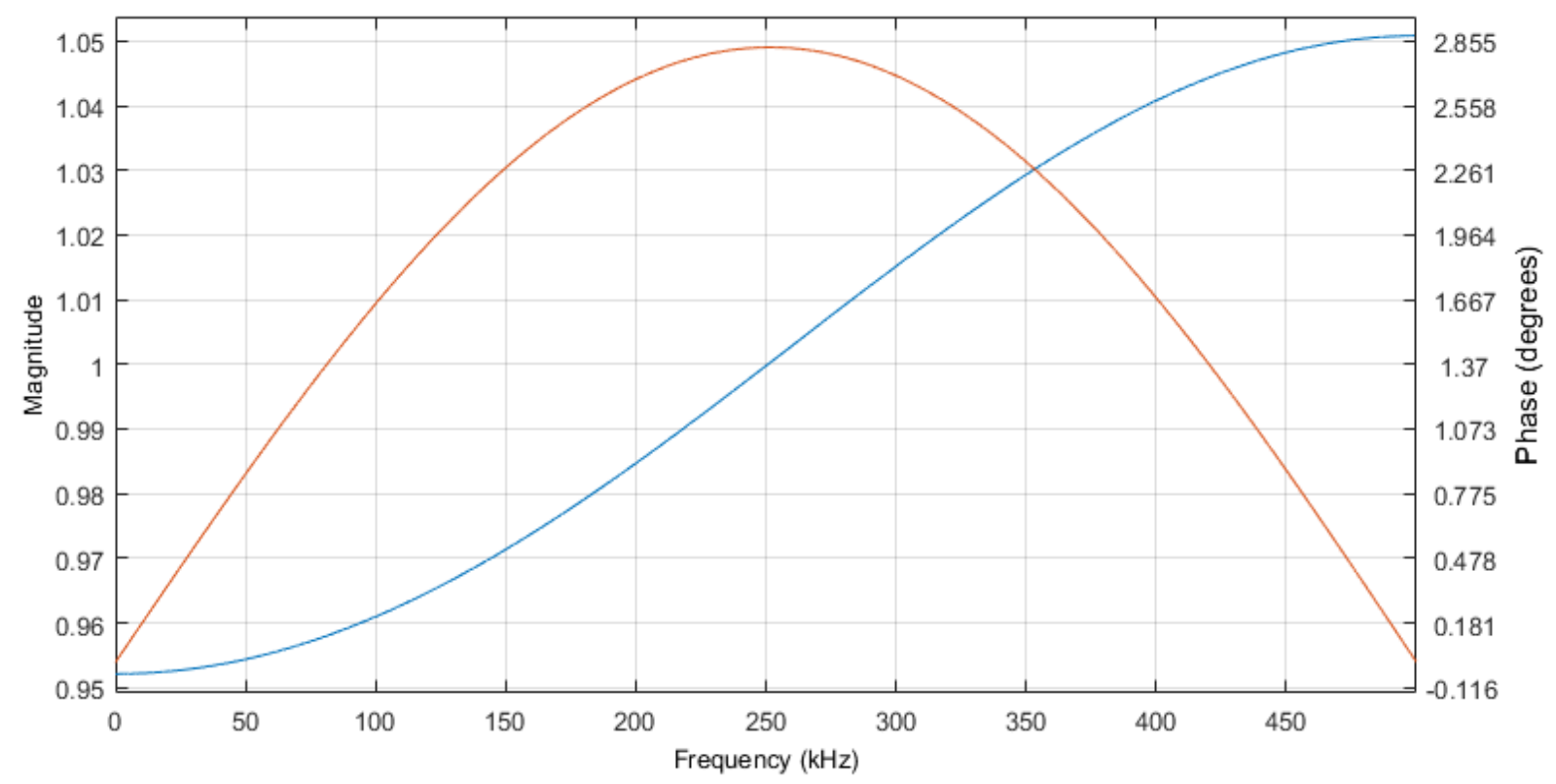

Figure 1. AFR and PFR of filter, synthesized in Matlab environment 
The input signal (synchronously registered FCS and ECS) has the form:

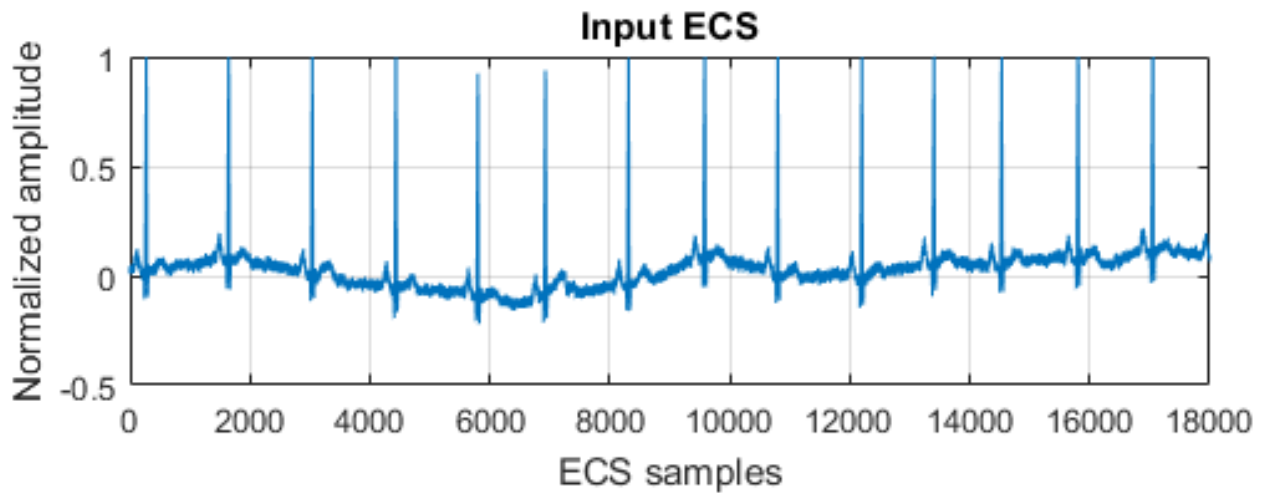

Input PCS

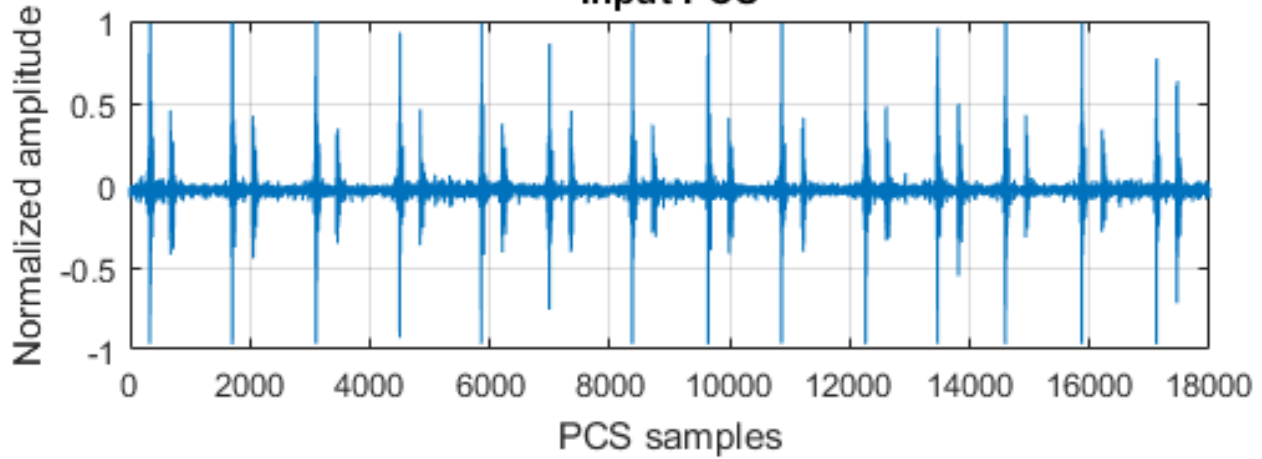

Figure 2. The input signal - synchronously registered FCS and ECS

ECS filtered by using hardware (without trend) has the form:

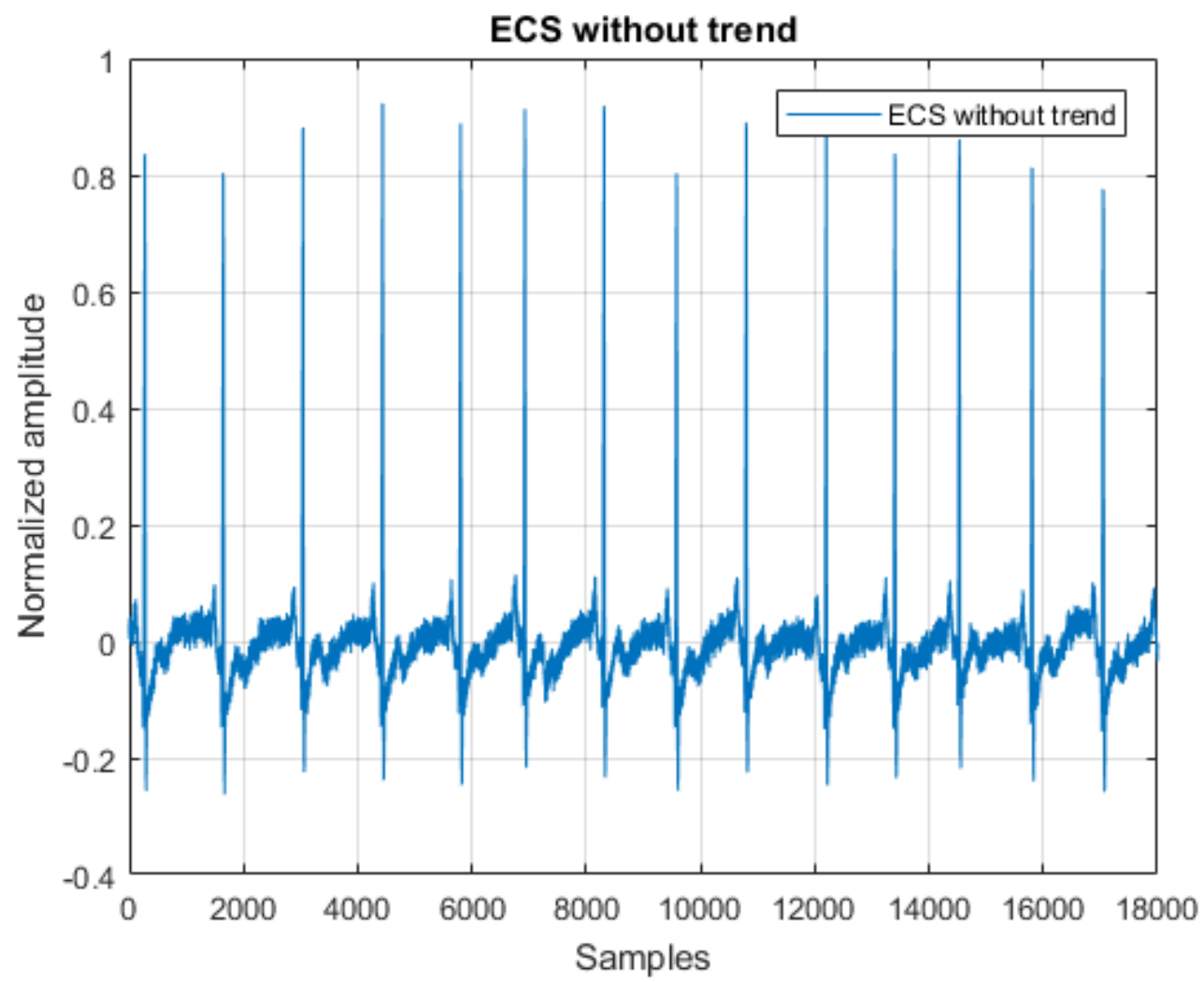

Figure 3. ECS without trend 
The next step is the R-waves location finding «on the fly» by the threshold method.

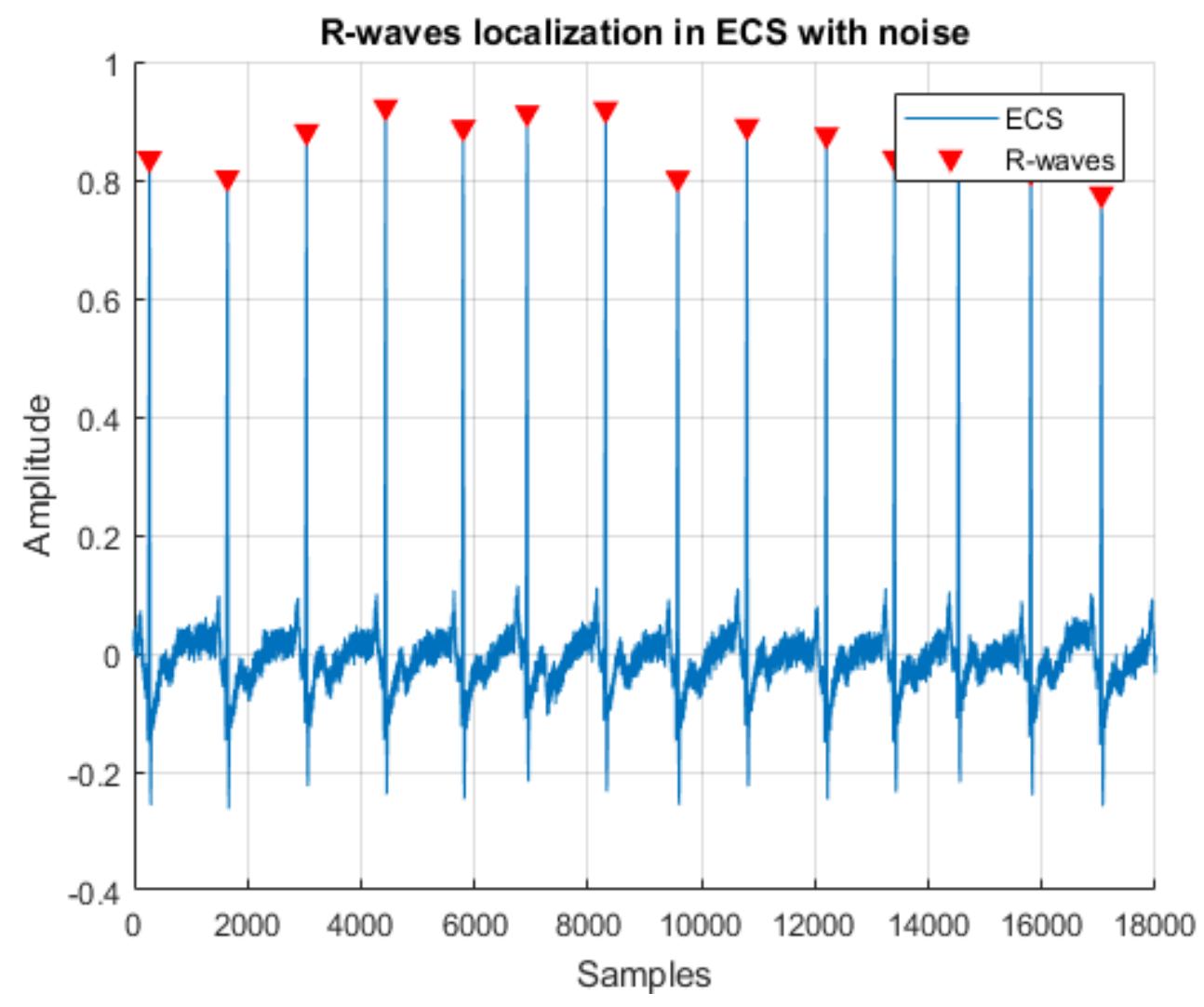

Figure 4. R-waves localization in ECS

Based on Slutsky's rule that the dynamic system after disturbance asymptotically approaches the new balance state, the PCS is registered and processed only on the organism homeostasis condition - the RR-interval varies with an absolute deviation of 5\%, it means that the heart rate is relatively stable.

In order to reduce the computational resources and based on the equations grounded by V.L. Karpman, P-wave is not searched at the entire RR-interval, but in the range of it possible localization.

Since the P-wave is much smaller than the $R$ one and its shape is more smooth, it is more distorted under the high-frequency noise impact. To find correctly maximums localization with high accuracy on low signal to noise ratio values condition is problematic. The low frequency filters usage is unacceptable, since they, in addition to phase distortions, cause strong sharp waves shape distortion and shifted them in time (strongly distort signals having discontinuity of the first kind).

In our case, a high-frequency noise is uncorrelated with a significant signal.

Then it is advisable to use smoothing methods. One of the most commonly used technics used for signals processing in many industries [16] is different kinds of moving average methods. In the general case, the moving average is numerically equal to input sequence arithmetic average at the specified range. The method of the modified moving average is a recurrence ratio, for which each subsequent value of the filtered sequence depends on the previous one. In addition to these, there are moving methods also based on the other average functions, in particular, the moving median model.

In data processing systems other processing methods are also used including spline interpolation in particular, in this case the recalculated subsequence values on each individual segment are characterized by a given polynomial order which coefficients have to be 
calculated. However, the methods listed above are not suitable for ECG processing, since they cause significant distortions in the signal with sharp short peaks.

The smoothing method by Savitzky-Golay [15] filter becoming increasingly widespread, in this case instead of the linear approximation in the neighborhood of each point of the sequence an aproximating $n$-th order polynomial is constructed by the least squares method in a certain length window. This sequence reconstruction back is performed by the smaller polynomial order calculation. The smoothing Savitzky-Golay filters (polynomial non recursive filters) are used for wide spectrum noisy signals smoothing (in the narrow sense). Such filters yield a much better result than ordinary non-recursive averaging filters (with ability to significant proportion of high-frequency significant signal components removing) make minimal phase distortions which is a critical condition for signal processing by synphase method. However, this smoothing method provides a bit worse noise attenuation compared to commonly used non-recursive filters, which requires a bit more computing resources. Since such a filtration provides a polynomial approximation of the input sequence individual frames by the minimum of the mean square error criteria that's why in this sense it is optimal.

Thus, the Savitsky-Golay filter is the most optimal technique, which does not distort the significant signal form under the optimal choosing of polynomial order and of the smoothing window width.

For the smoothing process quality estimation, we use two criteria:

- the P-wave maximum deviation value (horizontal displacement) after ECS and 1/0,05 amplitude ratio white noise additive mixture smoothing using Savitsky-Golay filter;

- the mean square deviation between real and filtered ECS.

The results are summarized in two tables.

The first one (Table 1) illustrates the P-wave maximum deviation dependence on the frame length and the smoothing polynomial order.

Table 1

The P-wave maximum deviation dependence on the window length and the Savitsky-Golay filter smoothing polynomial order

\begin{tabular}{|c|c|c|c|c|c|c|c|c|c|c|c|}
\hline \multirow{2}{*}{ Deviation, $m s$} & \multicolumn{11}{|c|}{ Filter frame length $F$} \\
\hline & & 13 & 15 & 17 & 19 & 21 & 23 & 25 & 27 & 29 & 31 \\
\hline \multirow{10}{*}{ 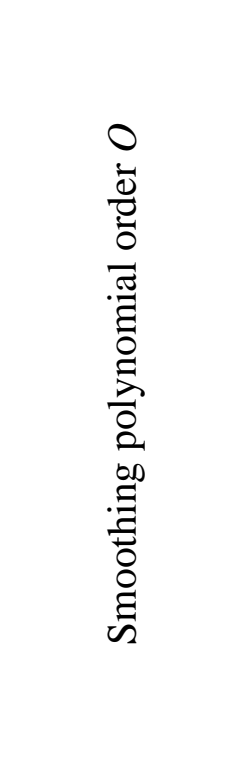 } & $m$ & 8 & 7 & 7 & 7 & 6 & 5 & 5 & 5 & 3 & 2 \\
\hline & $\forall$ & 7 & 7 & 7 & 6 & 5 & 5 & 4 & 4 & 2 & 2 \\
\hline & $n$ & 7 & 7 & 6 & 5 & 5 & 4 & 4 & 2 & 2 & 2 \\
\hline & 6 & 7 & 6 & 5 & 5 & 4 & 4 & 2 & 2 & 2 & 1 \\
\hline & - & 6 & 5 & 5 & 4 & 3 & 2 & 2 & 2 & 2 & 1 \\
\hline & $\infty$ & 5 & 5 & 4 & 4 & 2 & 2 & 2 & 2 & 1 & 1 \\
\hline & $a$ & 5 & 4 & 4 & 2 & 2 & 2 & 2 & 2 & 1 & 1 \\
\hline & $\stackrel{0}{ }$ & 5 & 4 & 2 & 2 & 2 & 2 & 2 & 1 & 1 & 0 \\
\hline & 三 & 3 & 2 & 2 & 2 & 2 & 1 & 1 & 1 & 1 & 0 \\
\hline & 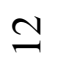 & 2 & 2 & 2 & 1 & 1 & 1 & 1 & 0 & 0 & 0 \\
\hline
\end{tabular}


The second one (Table 2) illustrates the mean square deviation between real and filtered ECS dependence on the frame length and the smoothing polynomial order.

\section{Table 2}

Mean square deviation between real and filtered ECS dependence on the frame length and the Savitsky-Golay filter smoothing polynomial order

\begin{tabular}{|c|c|c|c|c|c|c|c|c|c|c|c|}
\hline \multirow{2}{*}{ Deviation, $m s$} & \multicolumn{11}{|c|}{ Filter frame length $F$} \\
\hline & & 13 & 15 & 17 & 19 & 21 & 23 & 25 & 27 & 29 & 31 \\
\hline \multirow{10}{*}{ 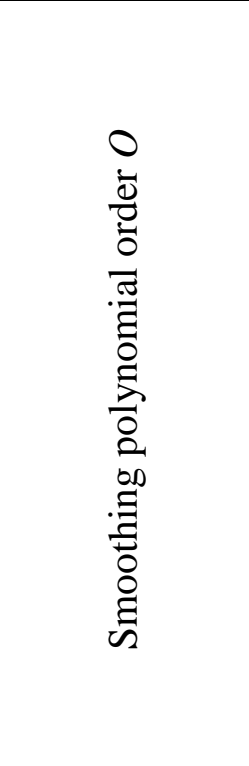 } & $m$ & 0,393 & 0,364 & 0,343 & 0,326 & 0,313 & 0,302 & 0,292 & 0,284 & 0,275 & 0,271 \\
\hline & $\nabla$ & 0,501 & 0,464 & 0,434 & 0,407 & 0,385 & 0,367 & 0,352 & 0,340 & 0,329 & 0,319 \\
\hline & $n$ & 0,503 & 0,465 & 0,434 & 0,408 & 0,386 & 0,368 & 0,353 & 0,340 & 0,330 & 0,319 \\
\hline & 6 & 0,592 & 0,547 & 0,513 & 0,484 & 0,459 & 0,436 & 0,416 & 0,398 & 0,381 & 0,368 \\
\hline & $r$ & 0,593 & 0,547 & 0,514 & 0,485 & 0,459 & 0,436 & 0,416 & 0,397 & 0,382 & 0,370 \\
\hline & $\infty$ & 0,684 & 0,626 & 0,580 & 0,549 & 0,521 & 0,497 & 0,476 & 0,456 & 0,439 & 0,419 \\
\hline & $a$ & 0,684 & 0,631 & 0,582 & 0,549 & 0,521 & 0,498 & 0,476 & 0,457 & 0,438 & 0,423 \\
\hline & $ㅇ$ & 0,790 & 0,707 & 0,654 & 0,610 & 0,576 & 0,548 & 0,526 & 0,506 & 0,487 & 0,471 \\
\hline & $=$ & 0,791 & 0,707 & 0,656 & 0,613 & 0,578 & 0,549 & 0,526 & 0,506 & 0,487 & 0,470 \\
\hline & $\simeq$ & 0,943 & 0,804 & 0,726 & 0,674 & 0,636 & 0,602 & 0,573 & 0,548 & 0,530 & 0,511 \\
\hline
\end{tabular}

For minimization problem solving the of fastest descent along intersection curve of parameter dependency planes gradient method is used.

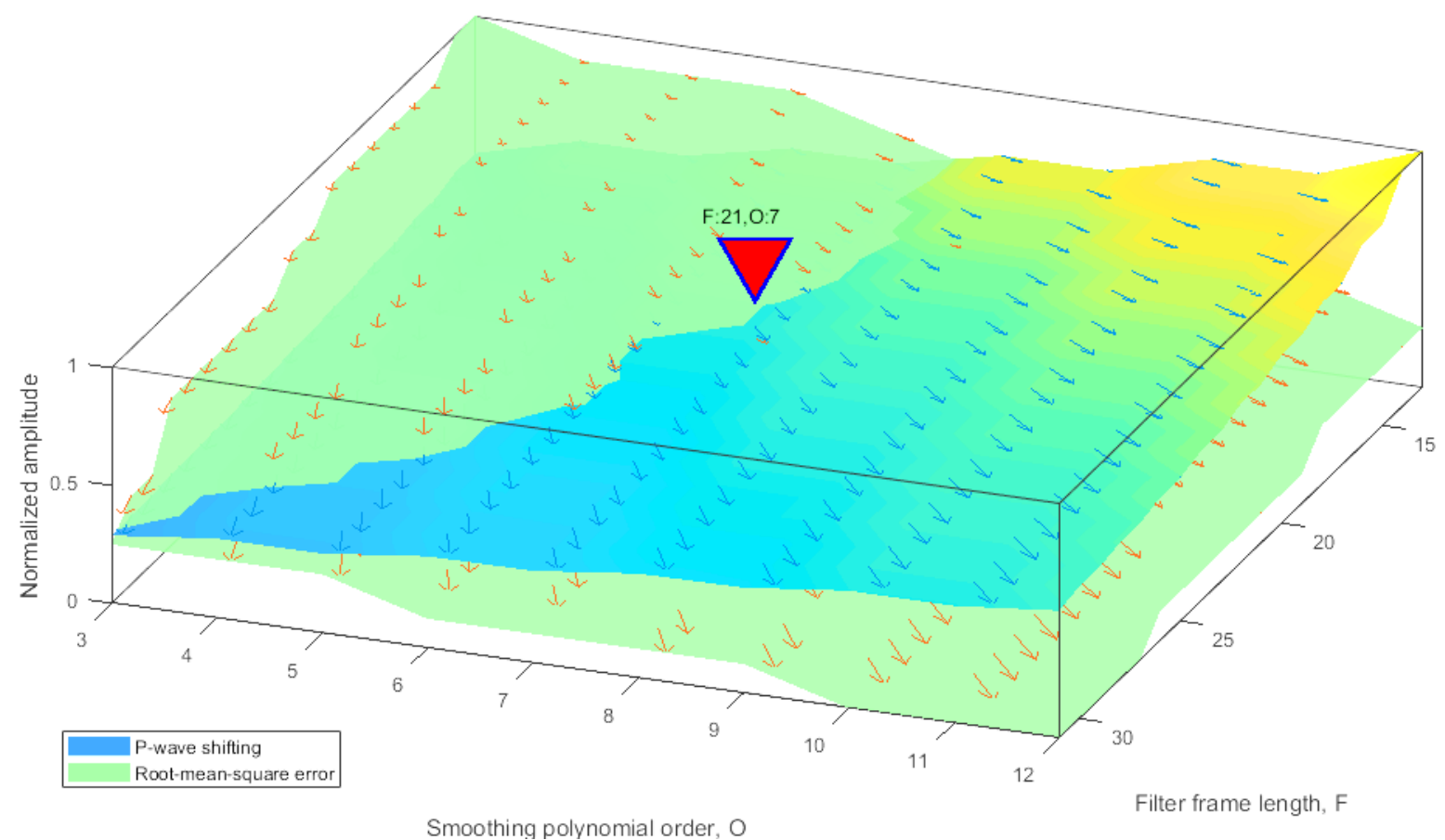

Figure 5. The Savitsky-Golay filter optimal parameters choice optimization problem solving 
The threshold method is used to find P-wave, since now there is no need to use different types of pattern recognition, pattern search, or transition to another area (for example, time to frequency domain transformation using Fourier transform, wavelet scaling coefficients).

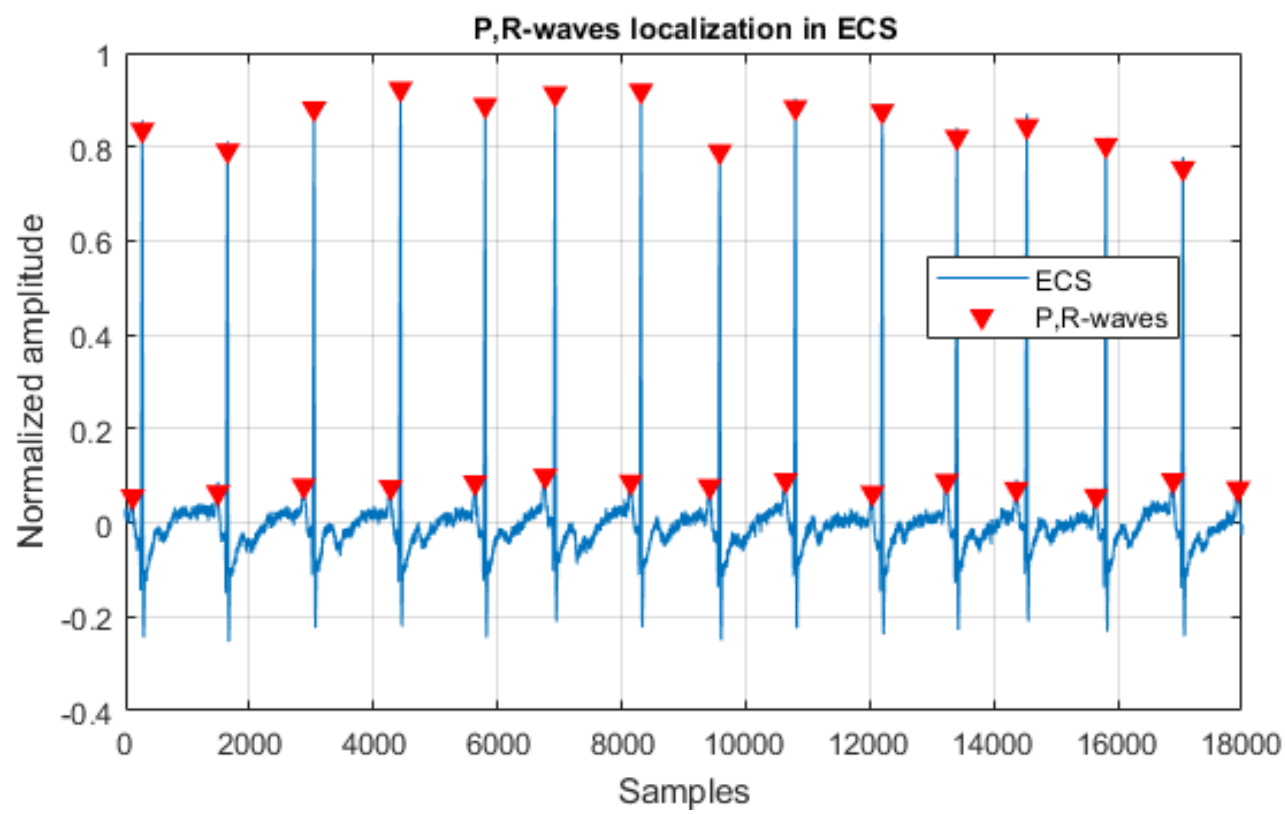

Figure 6. R-waves and P-waves localization in ECS

Conclusions. The applied preliminary processing algorithm makes it possible to reduce the noise negative influence during the FCS processing by synphase method and increase the results repeatability.

\section{References}

1. World Health Organization Regional Office for Euro. European mortality database (MDB). Available at: http://data.euro.who.int/hfamdb/ (accessed 06. 2016).

2. Drahan Y. Enerhetychna teoriia liniinykh modelei stokhastychnykh syhnaliv, Lviv, Tsentr stratehichnykh doslidzhen eko-biotekhnichnykh system, 1997, Vol. 16, 333 p. [In Ukrainian].

3. Baievskyi R.M. Ballystokardyohrafyia, Sofyia, Yzd-vo "Medytsyna y fyzkultura", 1971, 365 p. [In Russian].

4. Lupenko S.A. Teoretychni osnovy modeliuvannia ta opratsiuvannia tsyklichnykh syhnaliv v informatsiinykh systemakh, Naukova monohrafia, Lviv, Mahnoliia, 2016, 344 p. [In Ukrainian].

5. Lupenko S.A. Statystychnyi sumisnyi analiz kardiosyhnaliv na osnovi vektora tsyklichnykh rytmichno poviazanykh vypadkovykh protsesiv, Elektronika ta systemy upravlinnia, Vol. 4 (18), Kiev, NAU, 2008, pp. 22 - 29 [In Ukrainian].

6. Baevskyi R.M. Vremennaia orhanyzatsyia funktsyi y adaptyvno-prysposobytelnaia deiatelnost orhanyzma, Teoretycheskye y prykladnые aspektы analyza vremennoi orhanyzatsyy byosystem, Moskva, Nauka, pp. 88 - 111 [In Russian].

7. Palaniza Y.B. Suchasni pidkhody do opratsiuvannia fonokardiosyhnalu ta matematychna model yoho u vyhliadi periodychno korelovanoho vypadkovoho protsesu, Visnyk Khmelnytskoho natsionalnoho universytetu, Tekhnichni nauky, 2016, No. 2 (235) pp. 90 - 93 [In Ukrainian].

8. Dragan Y.P. Systemnyi analiz statystychnoho otsiniuvannia staniv stokhastychnoi vibratsiinoi systemy $\mathrm{i}$ pryntsypu shuntuvannia, Naukovyi visnyk NLTU Ukrainy, Zbirnyk naukovo-tekhnichnykh prats, Lviv, NLTU Ukrainy, 2015, No. 25.10, pp. 255 - 259 [In Ukrainian].

9. Drahan Y.P., Osukhivska H.M., Sikora L.S., Chorna L.S., Yavorskyi B.I. Statystychnyi analiz zasobamy enerhetychnoi teorii stokhastychnykh akustychnykh syhnaliv u problemakh meddiahnostyky, Kompiuterni tekhnolohii drukarstva, Lviv, UAD, 1998, pp. 111 - 113 [In Ukrainian]. 
10. Dragan Y.P., Sikora L.S., Yavorskyi B.I. Osnovy suchasnoi teorii stokhastychnykh sygnaliv: energetychna kontseptsiia, matematychnyi aparat, fizychne tlumachennia, Tsentr stratehichnykh doslidzhen ekobiotekhnichnykh system, 1999, 133 p. [In Ukrainian].

11. Kotelnykov S.A., Nozdrachev A.D., Odynak M.M., Shustov E.B., Kovalenko Y.Y., Davidenko V.Yu. Varyabelnost rytma serdtsa: predstavlenyia o mekhanyzmakh, Fyzyolohyia cheloveka, 2002, No. 1, pp. 130 - 143 [In Russian].

12. Dragan Y.P., Palianytsia Y.B., Hevko O.V., Dediv I.Y. Obgruntuvannia struktury systemy dystantsiinoi diahnostyky adaptatsiinykh rezerviv sertsia, Naukovyi visnyk NLTU Ukrainy, Zbirnyk naukovotekhnichnykh prats, Lviv, NLTU Ukrainy, 2015, No. 10, pp. 255 - 259 [In Ukrainian].

13. Palianytsia Y.B., Shadrina H.M. Obgruntuvania vyboru alhorytmu poperednoho opratsiuvannia fonokardiosygnalu yak periodychno korelovanoho vypadkovoho protsesu, Materialy XIX naukovoi konferentsii Ternopilskoho natsionalnoho tekhnichnoho universytetu imeni Ivana Puliuia, zb. tez dopovidei, 18 - 19.05.16, Ternopil, TNTU, 2016, 117 p. [In Ukrainian].

14. Oppenheim Alan V., Ronald W. Schafer, and John R. Buck. Discrete-time Signal Processing. 2-nd Ed. Upper Saddle River, NJ, Prentice Hall, 1999.

15. Tsyfrovaia obrabotka syhnalov [Elektronnyi resurs], Teoryia y praktyka tsyfrovoi obrabotky syhnalov. Available at: http://www.dsplib.ru/index.html (accessed 27.09.2018).

16. Nykonov A.V., Davletshyn R.V., Yakovleva N.Y., Lazarev P.S. Fyltratsyia metodom Savytskoho-Holeia spektralnыkh kharakterystyk chuvstvytelnosty matrychnыkh fotopryemnыkh ustroistv, Uspekhy prykladnoi fyzyky, 2016, Vol. 4, No. 2, pp. 198 - 205 [In Russian].

\section{Список використаної літератури}

1. European mortality database (MDB) [Electronik resource] : World Health Organization Regional Office for Euro, July 2016. - Mode of access: http://data.euro.who.int/hfamdb/ (accessed 06. 2016).

2. Драган, Я. Енергетична теорія лінійних моделей стохастичних сигналів [Текст] / Я. Драган. Львів : Центр стратегічних досліджень еко-біотехнічних систем, 1997.

3. Баєвський, Р.М. Баллистокардиография [Текст] / Р.М. Баєвський, А.А. Талаков. - София : Медицина и физкультура, 1971. - 365 с.

4. Лупенко, С.А. Теоретичні основи моделювання та опрацювання циклічних сигналів в інформаційних системах : Наукова монографя [Текст] / Лупенко С.А. - Львів : Магнолія. - 2006; 2016. -344 c.

5. Лупенко, С.А. Статистичний сумісний аналіз кардіосигналів на основі вектора циклічних ритмічно пов'язаних випадкових процесів [Текст] / С.А. Лупенко, Я.В. Литвиненко, А.С. Сверстюк // Електроніка та системи управління. - № 4 (18). - К. : НАУ. - 2008. - С. 22 - 29.

6. Баевский, Р.М. Временная организация функций и адаптивно-приспособительная деятельность организма [Текст] / Р.М. Баевский // Теоретические и прикладные аспекты анализа временной организации биосистем. - М. : Наука. - С. 88 - 111.

7. Паляниця, Ю.Б. Сучасні підходи до опрацювання фонокардіосигналу та математична модель його у вигляді періодично корельованого випадкового процесу [Текст] / Ю.Б. Паляниця // Вісник Хмельницького національного університету. Технічні науки. - 2016. - Вип. 2 (235). - С. 90 - 93.

8. Драган, Я.П. Системний аналіз статистичного оцінювання станів стохастичної вібраційної системи i принципу шунтування [Текст] / Я.П. Драган, Ю.І. Грицюк, Ю.Б. Паляниця // Науковий Вісник НЛТУ України: Збірник науково-технічних праць. - Львів : РВВ НЛТУ України. - 2015. Вип. 25.10. - С. $255-259$.

9. Статистичний аналіз засобами енергетичної теорії стохастичних акустичних сигналів у проблемах меддіагностики [Текст] / Я.П. Драган, Г.М. Осухівська, Л.С. Сікора, Л.С. Чорна, Б.І. Яворський // Комп'ютерні технології друкарства. - Львів : УАД. - 1998. - С. 111 - 113.

10. Драган, Я.П. Основи сучасної теорії стохастичних сигналів: енергетична концепція, математичний апарат, фізичне тлумачення [Текст] / Я.П. Драган, Л.С. Сікора, Б.І. Яворський. - Л. : Центр стратегічних досліджень екобіотехнічних систем, 1999. - 133 с.

11. Вариабельность ритма сердца: представления о механизмах [Текст] / С.А. Котельников, А.Д. Ноздрачев, М.М. Одинак, Е.Б. Шустов, И.Ю. Коваленко, В.Ю. Давыденко // Физиология человека. - 2002. - № 1. - С. 130 - 143.

12. Обгрунтування структури системи дистанційної діагностики адаптаційних резервів серця [Текст] / Я.П. Драган, Ю.Б. Паляниця, О.В. Гевко, І.Ю. Дедів // Науковий Вісник НЛТУ України: Збірник науково-технічних праць. - Львів : РВВ НЛТУ України. - 2015. - Вип. 25.10. - С. 255 - 259. 
13. Паляниця, Ю.Б. Обгрунтування вибору алгоритму попереднього опрацювання фонокардіосигналу як періодично корельованого випадкового процесу [Текст] / Ю.Б. Паляниця, Г.М. Шадріна // Матеріали XIX наукової конференції Тернопільського національного технічного університету імені Івана Пулюя: зб. тез доповідей, 18 - 19.05.16 р. - Тернопіль : ТНТУ, 2016. - С. 117.

14. Alan V. Oppenheim. Discrete-time Signal Processing [Text] / Oppenheim, Alan V., Ronald, W. Schafer, and John, R. Buck. 2-nd Ed. Upper Saddle River, NJ : Prentice Hall, 1999.

15. Цифровая обработка сигналов [Электронный ресурс] : Теория и практика цифровой обработки сигналов. - Режим доступа: http://www.dsplib.ru/index.html (дата обращения 27.09.2018).

16. Фильтрация методом Савицкого-Голея спектральных характеристик чувствительности матричных фотоприемных устройств [Текст] / А.В. Никонов, Р.В. Давлетшин, Н.И. Яковлева, П.С. Лазарев // Успехи прикладной физики. - 2016. - Т. 4, №. 2. - С. 198 - 205.

УДК 57.087:519.21

\title{
ОБГРУНТУВАННЯ ВИБОРУ АЛГОРИТМУ ПОПЕРЕДНЬОГО ОПРАЦЮВАННЯ ФОНОКАРДІОСИГНАЛУ ЯК ПЕРІОДИЧНО КОРЕЛЬОВАНОГО ВИПАДКОВОГО ПРОЦЕСУ
}

\section{Юрій Паляниця; Свгенія Яворська; Галина Шадріна; Леонід Дедів}

\author{
Тернопільський начіональний технічний університет імені Івана Пулюя, \\ Тернопіль, Україна
}

\begin{abstract}
Резюме. Ціла низка екзогенних та ендогенних факторів чинить комплексний синергічний негативний вплив на стан сериево-судинної системи як основного адаптогена. Для його ранньої діагностики, зокрема у системах віддаленого моніторування, запропоновано використати фонокардіосигнал (синхронно зареєстрований з електрокардіосигналом), який у термінах системносигнальної концепції є переносником відомостей про морфофункціональний стан серия. Як модель фонокардіосигналу використано періодично корельований випадковий процес (оскільки ия модель $\epsilon$ адекватною до природи породження сигналу) та синфазний метод опрачювання, щчо дало змогу врахувати вплив нервової регуляції (синусового вузла як водія ритму). Синфазний метод вимагає забезпечення однорідності статистичного матеріалу та визначення періоду корельованості вхідної послідовності, який у випадку фонокардіосигналу може бути представленим як середня тривалість сериевого цииклу. Визначення його за тривалістю $R-R$ інтервалу не дає змоги забезпечити вибірку однієі окремої реалізачії, тобто інтервалу між моментами прояву дї синусового вузла, щцо на електрокардіограмі виявлясться Р-зубием. Тому запропоновано визначати одну реалізацію серцевого циклу як інтервал Р-Р. Наведено процедуру попереднього опрацуювання зареєстрованого сигналу за алгоритмом: детрендінг сигналу (позбавлення від тренду, постійної складової сигналу), згладжування (позбавлення від високочастотних шумів з мінімальним спотворенням спектру та зміщенням локалізацій Р-зубців), знаходження періоду повторюваності за Р-зубиями. Така модель фонокардіосигналу дає можливість удосконалення існуючих систем віддаленого кардіомоніторингу для виявлення змін у роботі серия на ранніх стадіях розвитку патологічного процесу шляхом упровадження нового класу інформативно-інваріантних ознак - спектральних компонент, отриманих у результаті опраиювання сигналу синфазним методом.
\end{abstract}

Ключові слова: біосигнал, кардіосигнал, фонокардіосигнал, математична модель, імітаційна модель, верифікація, алгоритми виявлення патологї серия, MATLAB.

Отримано 27.09.2018 